\title{
The Symbolic Function of Transmodernity
}

\author{
Andrea Mura ${ }^{1}$ \\ Open University
}

\begin{abstract}
In this article transmodernity will be described as the symbolic context within which, in the last decades, new formulations of selfhood and community have emerged that challenge consolidated representations of the world. The aim will be to examine and map out an illustrative range of discourses at the core of the transmodern scenario, highlighting the counterhegemonic potential of its symbolic function vis-à-vis modern representations of reality. In doing so, particular focus will be put on some of the major effects of globalisation, namely spatial displacement, virtuality and fragmentation, arguing that these factors help us to understand the 'critical' dimension of globalisation as a traumatic process of dislocation of social space. It is by scrutinising these factors that we grasp the ability of 'transmodern' formulations of space and community to challenge the position of modern discourses.
\end{abstract}

To speak is to fight, in the sense of playing, and speech acts fall within the domain of a general agonistics (Lyotard, 1979/1984, p. 10).

\section{Introduction}

In his 1983 lesson on the Enlightenment, Michel Foucault defines modernity as an attitude rather than an historical time:

Thinking back on Kant's text, I wonder whether we may not envisage modernity rather as an attitude than as a period of history. And by 'attitude,' I mean a mode of relating to contemporary reality; a voluntary choice made by certain people; in the end, a way of thinking and feeling; a way, too, of acting and behaving that at one and the same time marks a relation of belonging and presents itself as a task. A bit, no

\footnotetext{
${ }^{1}$ Research Associate, Oecumene Project. Correspondence concerning this article should be addressed to Andrea Mura. E-mail: andrea.mura@open.ac.uk
} 
doubt, like what the Greeks called an ethos (Foucault, 1984, p. 39).

The value of this passage is that it avoids fixed categories and historicist explanations while maintaining the relevance of modernity as a 'scenario' against which certain historical or social manifestations can be measured and understood. In the attempt to transpose the Foucauldian notion of 'attitude' upon a discursive plane it might perhaps be useful to point out that as 'a way of thinking and feeling', 'of acting and behaving', 'attitude' reflects, first and foremost, a way of engaging with contemporary reality through the symbolic forms of language. From this perspective, modernity and tradition can be thought of as the symbolic contexts within which certain 'attitudes' have moulded more or less coherent vocabularies around the theorisation of specific cultural and political paradigms. ${ }^{2}$

This article aims to examine a particular type of 'vocabulary', one that competes with tradition and modernity in the attempt to make the world 'readable': transmodernity. With this term I wish to transcend the classical definition of postmodernity as a specific historical epoch or sociological condition (exemplified by the prefix post- of postmodernity indicating a condition following modernity) highlighting a discourse-centred reading of this analytical category. My interest here will be to describe the capacity of transmodernity to figure as the discursive context within which, in the last decades, new formulations of selfhood and community have emerged, challenging the role of modern and traditional discourses. In order to do this, I will begin by focusing on globalisation, pointing to its ability to displace the symbolic coordinates that have organised established representations of the world so far. This linkage will then be used, in the last part of the article, to 'map out' an illustrative range of discourses which I consider to be central to the structuring of the transmodern symbolic scenario.

\section{Tradition, modernity and transmodernity: a discursive reading}

What does it mean for modernity, tradition and transmodernity to stand as discursive contexts through which definite sets of symbolic codes are articulated in their depiction of reality? In order to answer this question, and for the purposes of this article, we need to establish a central reference to a post-structuralist reading of language and, particularly, to the idea of an endless circulation and movement of meanings. From a post-structuralist position, it is well known that language is characterised by a continual fluctuation of meanings, resulting in the impossibility of grounding stable representations. To hold this position, however, does not exclude the possibility for more precarious or temporary representations to be formed as means of organising social and political life. In his early study of psychosis, for instance, Lacan observes that the impasse produced by the continuous sliding of the chain of signifiers is solved by virtue of a fiction establishing the illusion of a stable reference. This fiction, appearing in every type of discursive field, is made possible by the point de capiton, which 'retroactively and prospectively' organises a range of signifiers, thereby making a process of signification possible by

${ }^{2}$ A paradigm stands, here, as the inner logic informing the construction of a certain discourse: whether, for instance, its spatial representations and subjectivity formations privilege a principle of exclusivity and closure towards externality and alterity (dualism) rather than inclusiveness and openness (universalism).

Language and Psychoanalysis, 2012 (1), 68-87.

http://dx.doi.org/10.7565/landp.2012.0005 
condensing that universe of fluctuating elements into a fictional totality: a discourse (Lacan, 1955-56/1993, pp. 267-268). The term condensation is crucial here, for it highlights the ability of a discursive agglomeration to slow down the circulation of meaning and signifiers, freezing them within the borders of its discursive realm, and creating a sense of temporary closure. From this perspective, a 'discourse' can be thought of as a fictional totality or, in the words of Laclau, a 'structured totality articulating both linguistic and non-linguistic elements' (Laclau, 2006, p. 13). Now, I contend that broader agglomerations of signifiers than a discourse can be imagined. I am suggesting here that we consider linguistic space as marked by the imaginary existence of major poles of attraction that draw discourses and signifiers to them, creating constellations, around which fictional totalities of signifiers (discourses) condense and gravitate in apparent proximity to one another. These poles of attraction function as discursive meta-structures, or vocabularies, from which discourses draw. Hence, signifiers temporarily condense within discourses, while discourses temporarily gather, gravitate and condense around symbolic poles of attraction. It is by referring to such meta-structures that I propose to read major analytical categories such as tradition, modernity and transmodernity.

What explains the proximity of discourses around broader constellations is the repetition of certain signifiers that resonate in the manner in which they articulate dominant paradigms within each meta-structure, (e.g. dualism for modernity; fragmentation and over-development for transmodernity; universalism for Christian an d Islamic tradition). Although discourses within each constellation might express differing views over specific essential issues, their proximity in terms of shared language and styles of discourse allows the meta-structure to appear as a coherent history or discursive attitude. In other words, despite the way people themselves tend to describe a particular narrative, for instance as 'modern' or 'traditional', the description of broader constellations in terms of modernity, tradition and transmodernity needs to manifest a certain discursive resonance in the way the social is organised and accounted for. In the light of such a perspective, I take tradition, modernity and transmodernity as convenient indicators or indexes in the organisation of discourses; they figure as fictional horizons of the linguistic space, horizons to look upon in order to identify a series of more or less coherent discourses. As broader constellations, tradition, modernity and transmodernity can also be seen as imaginative containers - vocabularies delineating a plurality of discourses and embodying for that very reason the range of signifiers that each discourse articulates. In comprising specific constellations of signifiers and discursive representations, they also exert a certain symbolic appeal when new articulatory practices are set in motion. In this sense, they work as symbolic reservoirs from which discursive articulations draw in order to construct their respective representations. Naturally, discursive articulations are both enabling and constrained by their reference to these symbolic contexts, horizons, scenarios, or reservoirs. I should stress that neither discourses nor symbolic reservoirs are fixed, closed and stable totalities. The very fact that discursive agglomerations, whether discourses or symbolic reservoirs, remain temporary and fictional condensations of signifiers, overcoming at any one moment the inner fluidity of language, means that their temporary sense of closure remains exposed to contingent dislocation. The possibility is always present for them to release the elements that previously converged within their discursive and symbolic boundaries. A contingent historical event in a specific socio-political context - say, for example, the irruption of colonialism in the Middle East (Mura, 2012) - might engender the temporary dislocation of discourses in that setting, promoting the emergence of new articulations. Here, Ernesto Laclau interestingly deploys the Husserlian notion of desedimentation to account for precisely 
such contingent 'events' of displacement. While Edmund Husserl had deployed the notion of 'sedimentation' to mean the fixation and accretion of meaning, Laclau defines the social as the space of 'sedimented' discursive practices whose 'contingent' institutionalisation is forgotten as a result of their very routinisation (Husserl, 1937/1970). Such a closure is, however, always exposed to crisis, dislocation or desedimentation through which the naturalisation of discursive practices is contested, social relations unsettled, the unity of a certain field of discursivity disarticulated and meanings de-fixed. It is here that a new hegemonic competition between discursive practices is again possible. This competition implies the reactivation (another Husserlian term) of contingency and decision; in other words, the reactivation of the 'political' against the sedimented space of the 'social' (Laclau, 1990). According to Laclau, this impulse marks the sign of a strict analogy between social and linguistic structures, for they are both given as impossible. There will always be a constitutive outside enacting while simultaneously disrupting a claim to totality of a certain discursive and social realm. As Laclau puts it, by highlighting the psychoanalytical dimension of his discursive theory: 'The centrality of hegemonic relations in discourse theory comes from the fact that the desire for fullness is always present, but fullness, as such, is unachievable and can only exist circulating among particularities which assume temporarily the role of incarnating it' (Laclau, 2005, p. 6). The inescapable presence of a discursive exterior will always entail a 'surplus of meaning' in any signifying space (discursive and social), one which no discourse can finally exhaust. In the end, no articulation will be able to avoid the ultimate contingency of signification.

In the light of such a framework, it can be argued that modernisation figured in Western settings as the desedimenting event of a process of increasing technological and economic development (industrialisation and mechanisation) and growing social articulation that disrupted the symbolic coordinates of tradition. This desedimenting process was, however, accompanied by the emergence of a new and alternative symbolic horizon through which reality was made readable: modernity. This symbolic reservoir condensed a range of new discourses that challenged the role of traditional Western narratives (e.g. pre-modern and medieval universalism, geocentrism, theism, etc.). Similarly, the increasing colonial interference of Western powers in non-Western settings and the structural transformations produced by the integration of colonial modes of production, engendered new desedimenting effects in colonial areas - those places where distinct typologies of tradition were in place (Islamic, Indian, Japanese, etc.). By assuming the same perspective, this article proposes to read globalisation as a new desedimentation process, one that challenged the symbolic structure of modernity, decentring its ability to provide standard ideological and discursive coordinates in the representation of the world. This process is, in turn, accompanied by the emergence of transmodern discourses, which once again provide an alternative reading of world reality. Before examining how this process occurred, it will be useful to clarify briefly the manner in which I will consider the semiotic structure of modernity and elucidate its discursive morphology. Three main sources have contributed to developing the symbolic horizon within which a plurality of 'modern' discourses has been articulated. First, a 'structural' connotation of modernity has been advocated by so-called modernist theorists and has supplied a number of socio-economic categories which have been central to its discursive development (e.g. discourses on industrialisation conducive to social and institutional differentiation; scientific rationality; the belief in progress; secularisation; and the thesis of deprivatisation of religiosity). Second, an 'ideological' connotation in which modernity has been understood by critics as an ideological construct grounded in 
the elaboration of specific political paradigms (i.e. the deployment of a binary logic in the theorisation of modern subjectivity, modern sovereignty, nationalism, colonialism, liberalism, and so forth). Third, since the nineteenth century a number of philosophers have described a plurality of moral dilemmas as eminently 'modern', thus enriching the symbolic structure of modernity with a 'moral' connotation (e.g. discourses of individualism, atomism, alienation, relativism, materialism, etc.). Modernity, then, emerges as a language in which most of these discursive elements have played a central role (from the nation-state to the idea of progress, from the rigid deployment of dualisms in the definition of political and social reality to individualism, etc.).

In the following pages, I examine the way in which three major effects of globalisation spatial displacement, virtuality and fragmentation - have contributed to a desedimentation of the symbolic representation of the world of modern discourses, enabling transmodernity to challenge their hegemonic position. While the tension between modernity and transmodernity will be highlighted with special attention, I will give only a cursory mention to tradition. My reason for this choice is that the link between modernity and transmodernity is to be considered at a general level, rather than focusing on concrete cultural or geographical settings where specific modes of articulating traditional symbolic reservoirs are set in motion.

\section{The Global Context: Spatial displacement, virtuality and fragmentation}

According to David Harvey, a basic feature of globalisation and one that is constitutive of a new human predicament - the so-called 'postmodern condition' - can be found in what he calls 'time-space compression'. This expression refers to the general tendency of 'capitalist modernization to be very much about speed-up and acceleration in the pace of economic processes and, hence, social life' (Harvey, 1990, p. 230). A continuous acceleration of the time of production and circulation of exchange enabled capital - in a process of increasing mobility and internationalisation - to erode spatial barriers, melting differentiated places into a global indistinct space, and transforming local economies into a global market. Technology has played a central role in this context, bringing about dramatic transformations in the way in which space, time and communication are perceived. The term I use to refer to this process here is spatial displacement, by which I mean a sort of double movement produced by globalisation and informatisation, which enacts both the dislocation and re-shaping of notions of space and related cognitions of time. In the early days of informatisation, the expression 'electronic highway' was used to highlight the sense of optimism that informatisation gave rise to by promising to bridge the gaps between remote geographical areas of the world (Gore, 1995). What soon became clear, however, was that the information highway was not only the simple medium of our travelling, but was itself also a place (Jones, 1995, p. 11). Notions such as cyberspace - first used by William Gibson in his 1984 novel Neuromancer - and virtual reality, indicated not only the new technological structure of multimedia communication but also the emergence of a new way of experiencing space and reality. They expressed the double dimension involved in the process of spatial displacement as the dislocation of the way space and time were hitherto perceived, and the promotion, at the same time, of new formulations of reality. Cyberspace and virtual reality are important examples of the intimate link existing between the very process of spatial displacement and the recent phenomenon of virtuality. Virtuality is to be thought of as a new way of perceiving reality based on the deployment and inter-action of technological and computerised 
artefacts. Its novelty lies in its ability to problematise spatiality, temporality and institutionalised space (public and private spheres).

When considering spatiality, for example, virtuality blurs not only the phenomenological understanding of space, but also all that constitutes its inner referentials (e.g. presence and absence, closeness and remoteness, origin and destination). Media theorist Mark Nunes notes that social networking websites, chat rooms or simple emails encourage users to interact by using metaphors of proximity rather than distance (Nunes, 1995, p. 322). This phenomenon also modifies a further phenomenological referent: temporality. The immediacy of chat rooms, emails and file-sharing software permit an enduring and simultaneous interconnection across users. Moreover, new developments in informatisation, such as Ubiquitous Computing or Augmented Reality, contribute to modifying our very cognition of material things. Objects become sensible, moving in relation to our movements; listening, speaking, satisfying and anticipating everyday needs in a continuous and imperceptible way. In this scenario, virtuality - in the form of cyberspace - questions the otherwise modern institutionalisation of social space and its organisation around a public/private divide. As I shall discuss in more detail, a dominant paradigm or logic at the core of the symbolic structure of modernity has been the deployment of binaries in the construction of space and subjectivity. As anthropologist Talal Asad points out, central to the enactment of a dualistic paradigm in modern discourses was the elaboration of the notion of the 'secular':

what needs to be emphasized [...] is that the complex medieval Christian universe, with its interlinked times (eternity and its moving image [...]) and hierarchy of spaces (the heavens, the earth, purgatory, hell) is broken down by the modern doctrine of secularism into a duality: a world of self-authenticating things in which we really live as social beings and a religious world that exist only in our imagination' (Asad, 2003, p. 194).

Asad contends that the secular, with its endorsement of a dualistic logic, is a relatively recent construction. It was the modern creation of the 'social' as an 'all-inclusive secular space' that enabled people to think in terms of the secular, allowing them to distinguish the social from other domains such as that of the religious. Over the last decades, spatial displacement and virtuality have contributed to the desedimentation of modern binary constructions.

Emblematic of these transformations is the use of the term forum. Once referring to the wide and 'open court' of a Roman city in which the market was situated and administrative, religious, and juridical general affairs were undertaken, it embodied the realm of the outside where 'public' life was organised. Unlike its classical connotation, the term is now associated with a new gathering space in which the formation of public opinion has been relocated within its 'private' counterpart: the house. In the virtuality of the forum, subjects celebrate the contemporary figure of the indistinction between the public and the private, the spatial tension of speech that exceeds the dual field of the 
public and the private. Today, the Internet provides us with a new measure of publicness, whereby personal popularity is less and less dependent on public recognition outside in the street, and is increasingly reliant on the number of Google search-results pages in which one's name is listed, which takes place in the intimacy of one's home. This discussion highlights the way in which global and technological changes have been reshaping important levels of experience. Another major sign of globalisation, however, which I define as fragmentation, has also undermined established representations of space and subjectivity.

\section{Fragmentation}

The modern trend towards an increased blurring of binaries, and the capacity of virtuality to overcome the modern organisation of institutionalised space should be considered alongside the process of subjective decentring that globalisation and informatisation have fostered in the last decades. This is a process that I call fragmentation. While spatial displacement and virtuality suggest some form of dislocation occurring on established representations of space and time, a focus on fragmentation requires an examination of the particular disarticulation that modern constructions of subjectivity have undergone with the fading of modern binaries.

I pointed earlier to the intimate relation between globalisation and informatisation. I would now stress that this relation entails a critical transition: a movement from a period of mechanisation and industrialisation to that of a quantitative and qualitative domination of services and information in the domain of production. While the process of industrialisation remains, it has been transformed through the emergence of methods of production centring upon the utilisation and manipulation of information. This passage of transition has produced a dramatic change in the way in which social and political life is experienced. Despite problems related to spatial displacement, the structural transition from industrialisation to the informatisation of production has led to the sophistication and intensification of the modern construction of social space. This point can be better illustrated by referring briefly to the debate about individualism. As pointed out earlier, the reliance on a dichotomous organisation of social space along an inside/outside divide - for instance celebrating the enlightened triumph of secularity and rationality against religion - was central to the discursive development of modernity. Max Weber's wellknown description of the modern world as a 'disenchanted world' accounted for the secular erosion of the holistic and transcendental horizons that had followed the humanist revolution. The crucial point here had been the gradual enfranchisement from a higher, holy order to a re-centring on mankind (Weber, 1918/1946). In this context, liberals celebrated the emergence, expression and centrality of individuality vis-à-vis society.

Most modern constructions of subjectivity in fact defined the individual in a dual relation with his/her social and cultural outside. In an etymological sense, the individual came to figure as the ultimate and indivisible constituent of society, whose ontological essence (rationality, egoism, altruism, etc.) was to be singled out and preserved against the context of an outside social. In Benjamin Constant's famous discourse of 1819, for instance, 'the liberty of the Moderns' coincides with individual liberty. According to Constant, it differed from the 'liberty of the Ancients' precisely because the latter extolled the political autonomy of the community assimilating the 'peaceful enjoyment of individual independence' to its needs $(1819 / 1988$, p. 102). The problem for modern discourses was precisely how to articulate such a relation. Whether to preserve, for

Language and Psychoanalysis, 2012 (1), 68-87. 
instance, a radical focus on individual rights and private enjoyment vis-à-vis the cultural constraints of society and the administrative regimentation of the state, or to redefine the social in terms of the free and organic expression of individuals. There is, nonetheless, a further meaning to be conveyed by the expression 'disenchantment of the world', one that points to the modern sense of meaninglessness in the absence of those horizons that had traditionally given sense to every aspect of individual and social existence. A common moral concern for liberal philosophers was, in fact, the degeneration of individuality to forms of individualism or social atomism. This fading, firstly of the transcendent and then of the social horizon, brought about a condition of atomisation which I characterise as a critical loss of sociability. The impression here was that the modern focus upon individuals entailed a narrowing of perspective, with the threat of losing the wider view for the social in the face of an almost exclusive focus on individual life. The effects of this condition upon a democratic industrial society were widely discussed throughout the nineteenth and twentieth centuries. In a modern context, where material interest and conformity seemed to dominate, 'not only does democracy make every man forget his ancestors, but it hides his descendants and separates his contemporaries from him; it throws him back forever upon himself alone, and threatens in the end to confine him entirely within the solitude of his own heart' (De Tocqueville, 1835-1840/1863/2007, p. 370).

Individualism meant that individuals, as the ultimate constituents of society, no longer perceived their original relation to the whole (hence the notion of the atom as an isolated unit which literally 'can not be cut' or, again, in-dividual as an ultimate 'in-divisible' being). By over-emphasising their own raison d'être in regard to society itself, individuals ended by experiencing the crisis of a lost sociability where society was now to be maintained merely in the shadows. The modern sense of a loss of sociability therefore implied the shadowing of the social-outside as a consequence of the overemphasis upon the individual-inside. The great impact of modern discourses about man and society lay in their potential to dull social atomism by promising a new sense of belonging (to a nation, a religious community or a social class). Since individuality and sociality constituted the two poles of modern subjective relations, discourses such as nationalism and socialism attempted to resolve the problems of individualism by reestablishing the link between the individual and society. They proposed to reconstruct identities by promising to fill the void left by the lack of sociability, therein providing a new sense of belonging. In regard to this scenario, I contended that the recent overlap of communication and informatisation has contributed to the erosion of the modern binary organisation of space and subjectivity, with its separation between inside and outside and, in political terms, between the private and public. As Hardt and Negri observe: 'the liberal notion of the public, the place outside where we act in the presence of others, has been both universalized (because we are always now under the gaze of others, monitored by safety cameras) and sublimated or de-actualized in the virtual spaces of the spectacle. The end of the outside is the end of liberal politics' (2000, pp. 188-189). Baudrillard has similarly analysed the dissolution of modern paradigms in terms of 'obscenity':

Neither is public yet a spectacle, nor is private still a secret [...] The consumer society was lived under the sign of alienation; it was a society of the spectacle, and the spectacle, even if alienated, is never obscene. Obscenity begins when 
there is no more spectacle, no more stage, no more theatre, no more illusion, when every-thing becomes immediately transparent, visible, exposed in the raw and inexorable light of information and communication. We no longer partake of the drama of alienation, but are in the ecstasy of communication (Baudrillard, 1988, pp. 21-22).

It is within this transformation that I locate the shift from the alienated subject of the modern world to the fragmented subject of transmodernity, one which points to a process of de-centring of subjectivity. Unlike atomism, fragmentation does not occur as a result of lost sociability or from the incapacity to refer any longer to a society (no longer perceptible even as a trace). Instead, it stands as the outcome of a hyper-intensification of the modern binaries which had opposed individuals to society. Baudrillard uses the notion of 'hyperthelia' to indicate a critical process of over-development on the part of a system; the movement of a system beyond its own ends, of a model that supersedes the object it has striven to apprehend (1993). Such a notion is particularly useful when considering the kind of critical movement that I am proposing in relation to modern constructions. I argued that a constant process of intensification has led modern subjective constructions to over-emphasise the centre of the individual-inside against the social-outside. Following this same process of intensification and over-development, largely strengthened by the constant acceleration of capitalist processes and the effects of globalisation and informatisation, I contend that the increasing focus on the individual centre has paved the way for its critical fragmentation or implosion.

While the modern emphasis on the opposition 'individual-society' initially produced atomism, its inner over-development has brought about the disappearance of this opposition and the corresponding emergence of fragmentation. When modern subjectivity becomes fractured as a result of the fading of the binaries that lie behind its construction, then fragmentation emerges as a residual entity. It could be said that where the modern individual-self experiences a loss of sociability, the fragmented-subject produced by globalisation and informatisation experiences the loss not only of the public but also of the private. Being also deprived of the private, the fragmented subject experiences the loss of the modern Self. Hence a discursive universe that would aspire to appeal to a fragmented subject should start by inventing a new form of selfhood. Modern discourses such as nationalism and communism reconstructed identities by promising to fill the void left by the lack of sociability, thereby providing a new sense of belongingness. Hence, the modern symbolic appeal of signifiers such as 'corporatism', 'comradeship', 'fellowship' and lay or religious 'brotherhood' after the French Revolution, and their radicalisation under the experience of totalitarianism in the twentieth century. In a time in which both public and private vanish, a transmodern discourse points to the reinvention of notions of selfhood and community beyond any binary opposition to a specific outside.

\section{The transmodern symbolic reservoir}

Before mapping out the range of discourses and signifiers that have most contributed to the emergence of transmodernity as a symbolic reservoir, there is an important point that 
needs to be stressed. Although spatial displacement, virtuality and fragmentation are constitutive features of globalisation, it would be inappropriate to assert that they affect the entire world in the same manner and with the same intensity, producing similar problems of desedimentation everywhere. In some contexts, in coping with the challenge posed by modern discourses over their traditional equivalents, people might experience problems of excessive individualism, loss of sociability and social atomism. Other environments might be more sensitive to the desedimenting effects of globalisation, promoting new formulations of subjectivity beyond modern binaries (private vs. public, domestic vs. foreign, etc.). I am considering here a 'complex' linguistic matrix within which different symbolic reservoirs operate simultaneously, overlapping and even opposing each other with varying degrees of intensity. This is a crucial point, as the very term transmodernity has been used to avoid the common reading of post-modernity as an historical epoch or sociological condition replacing modernity.

In this article, although transmodernity and post-modernity are closely linked, they remain distinct notions insofar as the latter provides the former with an 'internal' discursive component, which, among other things, contributes to the consolidation of its morphological structure. As we will soon see, transmodernity figures as a broader discursive scenario incorporating both sociological and historical discourses about postmodernity as well as so-called postmodernist political and philosophical theories. The prefix trans- aims to highlight precisely the discursive complexity of transmodernity and its traversing of these specific domains (the historical, sociological or philosophical dimension of both post-modernity and post-modernism) as well as other discursive connotations. In addition, this prefix emphasises a specific modality of engagement with modernity. I consider trans-modernity, in fact, as a symbolic scenario finding its discursive condition of possibility in the very hyper-intensification of modernity described above. An example of the discursive complexity described here is the recent debate in psychoanalysis about the radical change that is allegedly occurring in our contemporary era concerning the 'end of the paternal dogma'; that is, the erosion of the transcendental function of the father (Tort, 2007). Here, the idea is that hyper- or postmodernity would be responsible for what has been called the 'decline of the Oedipus, where the paradigmatic mode of subjectivity is no longer the subject integrated into the paternal Law through symbolic castration' (Zizek, 2000, p. 248). Naturally, a major consequence of this view is the crisis of desire and the potential entry into a realm of perversion where enjoyment is no longer marked by the experience of the limit. Once castration is suspended, 'desire' ceases to be a key manifestation of the subject of the unconscious, and faces something akin to a 'nihilistic obliteration' which testifies to the birth of a new type of subject: the 'man without unconscious' (Recalcati, 2010, p. x). The point to be emphasised here is that whether the decline of the Oedipus is acknowledged or not depends upon which reservoir we use to 'read' social reality and the type of discourse that we are considering. Should we refer, for instance, to a discourse celebrating the limiting function of the Law, thereby promoting austerity, sacrifice, and prohibition, or to a discourse extolling the ideal of unlimited and dissipating enjoyment? Interestingly, Zizek points to the current coexistence of the modern discourse of democracy which manifests, on the one hand, a hysterical structure, valorising the central function of desire and, on the other hand, the multicultural discourse of late capitalism, with its perverse injunction to enjoy (Zizek, 2000, p. 248). In this respect, Zizek emphasises the contemporary overlapping of modernity and transmodernity, desire and perversion, politics and post-politics, conflict and illusion of perpetual peace within the general structure of the symbolic. 
Having established that transmodernity stands as a symbolic scenario alongside tradition and modernity, and that this scenario finds its 'paradigmatic' point of consistency in the over-development of modernity, it is possible to define transmodernity as the discursive condition under which modernity experiences a sense of crisis as the result of a higher degree of sophistication. Spatial displacement, virtuality and fragmentation intensify an over-development of modern binaries to a critical point of disruption, where modern conceptions of space and subjectivity fade. It is at this critical point that new transmodern formulations of selfhood and space are enacted and articulated, displaying their counterhegemonic action in the desedimented space of the social. But how can one account for transmodernity from a semiotic perspective? I argued that three main sources contribute to determining the modern scenario, each one condensing a more or less defined range of discourses (i.e. structural, moral and ideological). Naturally, the borders of such a categorisation are not clear-cut. They rather play a purely indicative function, distinguishing between different levels of the debate about modernity. It can be said, for instance, that discourses contributing to the ideological connotation of modernity, such as liberalism or socialism, partake also in the determination of a moral connotation of modernity focusing on individualism and alienation. Using this categorisation as a point of departure, I will now account for a range of discourses that have emerged as an effect of the process of desedimentation enacted by spatial displacement, fragmentation and virtuality. Again, the allocation of discourses to specific semiotic connotations of transmodernity is purely indicative insofar as each transmodern discourse might contribute to the definition of more than one connotation resonating on different levels.

\section{Transmodernity: An Ideological Connotation}

A point of departure for understanding the diverse range of problems that transmodern discourses have tackled is the well-known notion of 'postmodernity'. Over the last forty years, this term has evoked a plurality of approaches animating a dynamic ongoing debate. At first glance, the set of discourses that constitute the concept of 'postmodernism' define what could be understood as an ideological connotation of transmodernity. Postmodernist perspectives reflect the general attempt to question modernity and its related forms of power and knowledge. Whether through the analytical critique of rationality that emerged with the Enlightenment or through an evaluation of colonialism as a power practice intrinsically related to modernity, all these perspectives stand together in the contestation of essentialist and dichotomous modern paradigms and the common celebration of notions of difference and multiplicity. In the face of modern binaries hierarchically dividing the world between centre and periphery, civilised and uncivilised, colonial powers and colonised populations, post-modernist discourses focus on 'transnational citizenship' (Balibar, 2004), 'diaspora communities' (Bhabha, 1994), 'hybridity' (Brah \& Coombes, 2000), 'liminality' (D'haen \& Bertens, 1994), 'mestiza' (Anzaldúa, 1999), cyber identity (Haraway, 1991; Turkle, 1995), transgender (Stone, 1996) or 'nomadism' (Braidotti, 1994). They aim to deconstruct modern binaries, promoting the invention of anti-foundationalist and anti-dichotomous forms of selfidentification (the mestizo/a, the transgender, the cyborg, the nomad, etc., all categories used to go beyond the opposition between the white and the black, the masculine and the feminine, the organic and the inorganic, the domestic and the foreign, etc.). Social theorist Krishan Kumar, for one, points out that despite old essentialist approaches that continue to reside even amongst multiculturalist theorists, "the future appears as one of "hyphenation", "hybridity", "syncretization", "creolization", and the creative invention of "diaspora cultures" (Kumar, 2002, p. 60). These are all emblematic examples of the 
range of signifiers that postmodernist theories articulate, contributing to the symbolic definition of a transmodern discursive scenario.

Despite aspiring to promote political resistance, some 'critics' have described postmodernist tendencies as the 'ideological' superstructure of late capitalism (Jameson, 1991), which, for some, have followed the erosion of the left at the end of the Cold War (Anderson, 1998). The constitutive features of postmodernism have been located in the aesthetics of citationism, or in a mode of textual practice underlying the widespread adoption of a 'soft relativism' (Taylor, 1991). In a provocative and seminal essay, Habermas accused postmodernism of constituting a mere recurrence of a CounterEnlightenment project (Habermas, 1981). Notions such as 'liminal' or 'hybrid' identity, 'internationalism of people in the diaspora', as well as the attention given to local and sub-cultures or to the relativistic nature of culture itself, have constituted, for some critics, the very core of postmodernist ideological approaches. A postmodernist antifoundationalist perspective tends to use the play of difference and contingency against logocentric 'subjective' representations (gender, social, cultural, etc.) in the ultimate celebration of the pleasures of the 'local, the popular, and, above all, the body', thereby becoming a 'ludic postmodernism' (Ebert, 1996). Although able to deconstruct and disarticulate well-established holistic modern discourses and open up a new space for discursive articulations, for some critics postmodernism represents the ultimate product of late-capitalism and late-patriarchy. Far from providing an effective remedy against forms of domination, postmodern discourses have been seen as the 'symptoms of the passage' towards new forms of global governance (Hardt \& Negri, 2000). Hardt and Negri note that new economic and political powers have achieved a post-modernist mindset in recent years, thriving upon the very fluid subjectivities and micro-differences that postmodernism extols. New practices of marketing and consumption suggest the increasing valorisation of a postmodernist polity based on difference. 'Trade brings differences together and the more the merrier! Differences (of commodities, populations, cultures and so forth) seem to multiply infinitely in the world market, which attacks nothing more violently than fixed boundaries: it overwhelms any binary divisions with its infinite multiplicities' (Hardt \& Negri, 2000, p. 150). This position is supported by new developments in management and organisational theories which, in the last two decades, have increasingly drawn upon postmodern approaches, celebrating the mobility and flexibility of organisations and their ability to deal with difference. ${ }^{3}$ A multicultural and multiracial milieu is often celebrated by top managers of transnational corporations as the best strategy to maximise creativity, profit and consumption.

${ }^{3}$ Business courses about how to learn postmodernist management theory and achieve a postmodernist organizational attitude are mushrooming: "Postmodernists reject unifying, totalising and universal schemes in favor of a new emphasis on difference, plurality, fragmentation, and complexity [...]' (Best and Kellner, 1997). Join us in learning how to apply this new thinking to organizations!"; http://web.nmsu.edu/ dboje/TDworkshop Boston.html. See also http://business.nmsu.edu/ dboje/postmoderntheory.html where it is stated: "The value in looking at a postmodernist approach to chaos and complexity lies in getting beyond the reductionist thinking of "modernist" managers'.

Language and Psychoanalysis, 2012 (1), 68-87. 


\section{Transmodernity: A Structural Connotation}

Apart from the ideological connotation of transmodernity in the form of particular variants of postmodernism, other scholars have tackled 'post-modernity' as both a socioeconomic condition and a historical time. Unlike postmodernist theorists, their aim is not to devise political projects based on difference and multiplicity. They point rather to an analytical critique of post-modernity. The result is that a new array of discourses and signifiers has been produced, which enrich transmodernity with an historical and structural connotation. By expressing a diversified range of qualitative investigations, and semantic and terminological innovations, new conceptualisations have taken the analysis of post-modernity beyond Lyotard's seminal definition of it as the condition of 'incredulity towards metanarratives' (Lyotard, 1979/1984, p. xxiii). Hence, we find notions such as 'second modernity' or 'risk society' (Beck, 1992), 'network society' (Castells, 1996), 'late' or 'high' modernity (Giddens, 1991), 'liquid' modernity (Bauman, 2000), 'hypermodernity' (Lipovetsky \& Charles, 2005), 'transmodernity' (Rodríguez Magda, 2005; Dussel, 1995), 'supermodernity' (Augé, 1995), etc. In different terms and to different degrees, all these perspectives reflect the emergence of new discourses assuming postmodernity to be a definite historical phase or sociological reality with features of its own which would somehow progress beyond the social, political and linguistic constituents of 'modern time'. As amply debated, my categorisation of transmodernity encompasses the range of discourses that have emerged with globalisation and which define the ideological, historical and structural dimension of post-modernity. In this sense, I take these dimensions to express respective 'connotations' of the transmodern symbolic reservoir: not only post-modernist anti-foundationalist discourses celebrating difference and hybridity, but also historical, economic and sociological analyses of post-modernity assessing the constitutive features of this new 'reality'.

\section{Transmodernity: A Spatial Connotation}

In addition, I take transmodernity to include a number of discourses celebrating a new global or deterritorialised cognition of space and defining a spatial connotation of transmodernity. As I discussed earlier, a major effect of globalisation has been a process of spatial displacement, which has modified the way in which space is experienced, imagined and constructed. In addressing this predicament, new discourses have emerged which have reformulated the link between identity and space by overcoming the modern binary relation between the individual and his/her outside social and cultural context. A new relation has been constructed between a fragmented subject on the one hand and an indistinct externality on the other. That is, the globe, the depthless surface of the screen, cyberspace, various forms of potential communities or virtualities (communities to come, not yet realised, such as the perfect Islamic society, global citizenship) and various forms of already established multiplicities (the multitude, the global ummah etc).

Central to this movement is the increasing inability of people to firmly grasp external place. Notions such as 'universal placelessness' (Relph, 1976), 'release from gravity', 'megalopolis' (Olalquiaga, 1992), or 'geography of nowhere' (Kunstler, 1993) all illustrate a context in which spatial referentials have lost meaning, bringing about the discursive desedimentation of a whole signifying space and the formulation of new quests for personal and collective identities. Celeste Olalquiaga's notion of 'psychasthenia', for instance, refers to the condition of disorientation and the identity loss that occurs when external boundaries fade and the subject ends up losing itself in the vagueness of the outside space, assuming 'a ubiquitous feeling of being in all places while not really being 
anywhere' (1992, p. 2). If we consider the role of virtuality in moulding new discursive representations of reality, the fading of external boundaries and the corresponding impact of new subjectivity formations assume particular relevance. Baudrillard points to the hypertelic role of technology in producing what he sees as the 'liquidation of all referentials' (1994, p. 254). A complex global network of microchips and computer devices, the infinite reproduction of images and information, and the 'virtualisation' of everyday practices has led to a questioning of the very possibility of distance, engendering, in the words of Virilio, the 'perpetually repeated hijacking of the subject from any spatial-temporal context' (1991, p. 101). In this scenario, Baudrillard elaborates and articulates an emblematic transmodern signifier: hyperreality. By radicalising Borges's allegory of simulation, which envisages a map of the Empire so detailed as to cover the exact surface of its territory - thus not merely symbolising but literally substituting and merging with its object - Baudrillard perceives the age of media communication and informatisation through the emergence of a new order of reality in which a 'precession of simulacra' supplants physical referentials (1994). Although the Internet exemplifies this global trend, manifesting itself as a closed, self-contained networked totality that precludes the empirical interrelation with a beyond, this predicament encompasses 'an irradiating synthesis of combinatory models', a technological appropriation of the entire world by way of microchips, electric devices, satellites, etc. (Baudrillard, 1994, p. 254).

In this ultimate stage of simulacra, a phenomenological representation of space is lost in favour of a ubiquitous narcissistic void in which fractal identities fluctuate restlessly. Once we are everywhere - it suffices to be on-line - there is no longer a place defining our location and no longer an original 'fragment' of ourselves to be maintained. Fractality and ubiquity - our infinite division into self-same parts and the unceasing reproduction of them in the seriality of the matrix - are the corollary of simulation. Hence the narcissistic stupor of virtual travelling, which absorbs users into the microworld of their dreams. Baudrillard describes this process in terms of a transition from seductio, the seduction by the other for the other, to subductio, the hypnotic obscene fascination of the self, eternally reproduced in the narcissistic abyss of the screen (1988, p. 43). In a world characterised by the mobility of boundaries, the reformulation of identity mirrors de-centralisation, testifying to the fragmentation of subjectivity and the attempt to recover forms of spatial externality and collective identity beyond modern binaries. Some discourses celebrate cyberspace and the new era of virtual communities, while others assume a 'globalist' perspective; that is, they acknowledge 'interconnectedness' as a way to recover a sense of externality in which to locate the action of the fragmented subject. Space and subjects are re-composed in what Manuel Castells defines in terms of a 'network society', where a 'space of flows' (flows of people, goods, information) replaces the modern 'space of place' and creates a new 'interdependent' world reality (1996).

Globalist perspectives are often paralleled by rejuvenated universalistic discourses that point to the emergence of new collective subjects. A universalistic ethos is here recovered in the celebration of an inclusive dynamic which allows differences to be absorbed while preserving, at the same time, forms of political litigation. In the recently popularised notion of 'multitude', for instance, the celebration of this new collective subject entails the re-articulation of 'individuals' as 'singularities', and the preservation and integration of difference (Hardt \& Negri, 2004). Universalistic discourses can also draw upon eschatological representations, resonating with traditional religious discourses, as is the case with the revived ideal of a global ummah (Muslim community) among certain 
jihadist trajectories. These discourses show that certain parallels can be established between transmodernity and tradition. The result is that the desedimenting process enacted by globalisation might allow traditional discourses to be revitalised in opposition to modernity and in conjunction with transmodernity.

\section{Some remarks}

In the light of my discussion of the spatial connotation of transmodernity, a few caveats are required. First, it might be said that transmodern discourses celebrating the emergence of global actors or global space are the heirs of modern internationalism, although they reflect the overdevelopment of modernity. Internationalism refers to a context where modern binary notions of space and subjectivity play a hegemonic role. The very words internationalism and international suggest cooperation or coexistence amongst nations, rather than their replacement with a supra-national reality. It is true that internationalism might also be taken to express a world order deprived of national constructions; for instance, via the establishment of a federation of either communes or anarchist communities. However, we should also bear in mind that classic internationalist representations involved both the deployment of modern binaries to construct space and subjectivity, and a modern logocentric approach towards either the notion of 'humanity' or that of 'structure'.

The distinction between internationalist and universalistic discourses aligns with the differentiation between the modern notion of 'proletariat' and the transmodern concept of 'multitude'. Unlike the socio-economic conception of the proletariat, with its industrialist understanding of society and social class, the multitude marks the transition to an antifoundationalist notion of selfhood. It figures as a 'multiplicity of singularities, already creolised, embodying immaterial and intellectual labour' (Negri \& Zolo, 2005, n. pag). From a different angle, Virno observes that 'the notion of multitude seems to share something with liberal thought because it values individuality but, at the same time, it distances itself from it radically because this individuality is the final product of a process of individuation which stems from the universal, the generic, the pre-individual' (2004, p. 76). Hence, there remains a crucial difference in comparison with modern discourses, for unlike individuals, singularities do not stand as pre-constitutive 'solipsistic atoms' but figure as the complex and final outcome of the very process of differentiation of the multitude.

A second caveat concerns the complexity of forces that globalisation embodies and transmodernity aims to represent. All the discursive tendencies that I have described might entail either the celebration or rejection of difference. While some perspectives might share with postmodernist discourses the tendency to conceptualise global space in terms of hybridity and difference (in the guise, for instance, of a global multicultural society or the multitude where each of the singularities expresses a differentia specifica), other approaches advocate a standardisation of behavioural practices and values. Here homogeneity rather than heterogeneity is to be celebrated as the best way to confront global change. A case in point is the emphasis on homogenisation expressed by the increasing visibility of fundamentalist approaches to religion. Here we observe trends

\footnotetext{
${ }^{4}$ It is worth noting that in the attempt to reformulate the structural foundations of orthodox Marxism and anarchism, contemporary theoretical reflections such as post-Marxism and post-anarchism have also assumed an anti-foundationalist approach to subjectivity and space (Laclau \& Mouffe, 1987; Newman, 2009).
}

Language and Psychoanalysis, 2012 (1), 68-87. 
towards revivalism that conceive of tradition as a fixed set of values, and advocate a rigid and scriptural reading of the holy texts. These currents can produce a rejection of local cultures, where holy texts are reduced to a set of well-defined literal injunctions deprived of any cultural reference. The norms that are drawn from holy texts express a deculturised vision of religion, for they are taken to reflect the tenets of creed alone. They can consequently be used in any location, despite the cultural and social context of reference, so maintaining a universal validity that can be very useful in a globalised context (Roy, 2004)..$^{5}$

The above example illustrates the complexity of effects produced by globalisation. Heterogeneity and homogeneity coexist in the globalised context, paving the way for alternative discursive trajectories. This point has been well elucidated by geographer Edward Soja, who considered the production and re-production of urban space under globalisation to be the result of a tension between homogenisation and differentiation (1989). David Harvey maintains a similar complexity by acknowledging, together with the homogenisation of the world, the notion of an increasing heterogeneity of cultural, economic and political demands: 'spaces of very different worlds seem to collapse upon each other, much as the world's commodities are assembled in the supermarket and all manner of sub-cultures get juxtaposed in the contemporary city' (1990, p. 302). Such complexity is present in the conceptualisation of culture as well. In the face of spatial displacement we have seen that fundamentalist tendencies recover some form of authenticity by adopting a de-culturised version of religion based on a homogenised and rigid set of injunctions and norms drawn from the holy text and to be used in every context. Other trajectories, however, might react to globalisation by revitalising or reinventing their contact with the cultural setting. The erosion of modern conceptions of space might alternatively induce the revitalisation of traditional ideals of 'subnational' ties through a reinvigorated emphasis on sub-cultures and 'the local' vis-à-vis 'the global'. Hence the neologism 'g-localization' that some scholars have used to highlight this double dimension in the process of globalisation.

To conclude, a final remark is needed to address the link between transmodernity and tradition. I contended that the desedimenting effects of globalisation have, in many respects, jeopardised the hegemonic position that modern discourses have covered over the last century. A clear example is the enfeebling of the political role of the nation-state or the increasing inadequacy of modern binaries to cope with the changes produced by technology and informatisation. This predicament has spawned a twofold movement. On the one hand, transmodernity has emerged as a new discursive scenario alongside tradition and modernity. On the other hand, a reactivation of the symbolic appeal of tradition has allowed traditional discourses to be revitalised and re-articulated in a creative way, working alongside transmodernity to challenge the language of modernity. Here, tradition provides alternative symbolic sources to redefine space and subjectivity in a globalised world. I mentioned the emergence of discourses stressing the tribal and subnational character of identities. One example is the rejuvenated Arab notion of alasabiyyah (tribal solidarity) used by scholars to show how traditional forms of identification challenge the role of national narratives in Islamic settings (Sadiki, 2004). When compared with those transmodern reformulations of subjectivity that stress the

${ }^{5}$ I should stress that fundamentalism, in its Islamic dimension, should not be confused with Islamism, the latter expressing a wide range of revivalist perspectives which are not necessarily conservative, literalist, or homogenising.

Language and Psychoanalysis, 2012 (1), 68-87. 
supranational dimension of identity, it is clear that both these strategies reflect viable answers to the complex effects of globalisation, particularly with regard to its g-local character. The counter-hegemonic challenge to modern discourses that tradition and transmodernity promote is further characterised by some degree of resonance between the two reservoirs. The very rebirth of the concept of 'empire' or 'multitude' testifies to the transmodern attempt to rearticulate traditional signifiers in a manner adequate to the challenges posed within the new global context. In their essay on contemporary world order, Hardt and Negri point out that some traditional concepts such as Empire, bellum justum (just war) and jus ad bellum (right to make war) 'have reappeared in our postmodern world'. Though 'far from merely repeating medieval notions', these concepts 'present some truly fundamental innovations' (Hardt \& Negri, 2000, p. 12).

A further example is provided in this respect by Zielonka's analysis of the European Union, where a traditional conceptualisation of sovereignty is used to define the emergence of a 'neo-medieval' supranational entity: 'The [European] Union is on its way to becoming a kind of neo-medieval empire with a polycentric system of government, multiple and overlapping jurisdictions, striking cultural and economic heterogeneity, fuzzy borders, and divided sovereignty' (2006, p. vii). It is in consideration of all the discursive trajectories here elucidated that we can grasp then the symbolic function of transmodernity and its ability to mould new representations of the world.

\section{Conclusion}

By assuming a discourse-centred perspective, I have described a linguistic system marked by the coexistence of distinct discursive horizons through which our imaginaries are formed and regulated. I pointed here to the overlapping of three symbolic reservoirs modernity, tradition and transmodernity - which embody a number of discourses and the range of signifiers that such discourses articulate. My aim was to examine the symbolic function of transmodernity in particular, using this conceptualisation to account for those symbolic images which, over the last decades, have been articulated and deployed to construct new discursive representations of the world. In doing this, I assumed globalisation as a key desedimenting process of the social which dislocated the symbolic dominance of the modern vocabulary, enabling transmodernity and a reactivated tradition to disclose their counter-hegemonic potential and their symbolic function in making the world readable.

\section{Acknowledgements}

The research leading to these results has received funding from the European Research Council under the European Union's Seventh Framework Programme (FP7/2007-2013) / ERC grant agreement $n^{\circ} 249379$. 


\section{References}

Anderson, P. (1998). The origins of postmodernity. London, UK: Verso.

Anzaldúa, G. E. (1999). Borderlands/La Frontera: The New Mestiza. San Francisco, CA: Aunt Lute Books.

Asad, T. (2003). Formations of the secular: Christianity, Islam, modernity. Stanford, CA: Stanford University Press.

Augé, M. (1995). Non-places: Introduction to an anthropology of supermodernity. New York, NY: Verso.

Balibar, E. (2004). We, the people of Europe? Reflections on transnational citizenship. Princeton, NJ: Princeton University Press.

Baudrillard, J. (1988). The ecstasy of communication. New York, NY: Semiotext(e).

Baudrillard, J. (1993). The transparency of evil. New York, NY: Verso.

Baudrillard, J. (1994). Simulacra and simulation. Ann Arbor, MI: University of Michigan Press.

Bauman, Z. (2000). Liquid modernity. Cambridge, UK: Polity Press.

Beck, U. (1992). Risk society: Towards a new modernity. London, UK: Sage.

Bhabha, H. K. (1994). The location of culture. London, UK: Routledge.

Brah, A., \& Coombes, A. E. (2000). Hybridity and its discontents: Politics, science, culture. London, UK: Routledge.

Braidotti, R. (1994). Nomadic subject: Embodiment and difference in contemporary feminist theory. New York, NY: Columbia University Press.

Castells, M. (1996). The information age: economy, society and culture: Vol. 1. The rise of the network society. Cambridge, MA: Blackwell Publishers.

Constant, H.-B. (1988). The Liberty of the ancients compared with that of the moderns. In B. Fontana (Ed.), Political Writings (pp. 307-328). Cambridge, UK: Cambridge University Press. (Original work published 1819)

D'Haen, T., \& Bertens, H. (Eds.) 1994. Liminal postmodernisms: The postmodern, the (post-)colonial and the (post)feminist. Amsterdam, Netherlands: Rodopi B.V.Editions.

Dussel, E. (2005). The invention of the Americas: Eclipse of "the other" and the myth of modernity. New York, NY: Continuum.

Ebert, T. L. (1996). Ludic feminism and after: Postmodernism, desire, and labor in Late capitalism. Ann Arbor, NJ: University of Michigan Press.

Foucault, M. (1984). What is enlightenment? (Qu'est-ce que les Lumières?). In P. Rabinow (Ed.), The Foucault Reader (pp. 32-50). New York, NY, Pantheon Books.

Giddens, A. (1991). Modernity and self identity. Cambridge, UK: Polity Press.

Gore, A. (1995). Forging a new Athenian age of democracy. Intermedia, 22(2), (Summer), 4-6.

Habermas, J. (1981). Modernity versus postmodernity. New German Critique, 22, Special Issue on Modernism. (Winter), 3-14.

Haraway, D. (1991). Simians, cyborgs, and women: The re-invention of nature. London, UK: Free Association.

Hardt, M., \& Negri, A. (2000). Empire. London, UK: Harvard University Press.

Hardt, M., \& Negri, A. (2004). Multitude: War and democracy in the age of empire. London, UK: Hamish Hamilton.

Harvey, D. (1990). The condition of postmodernity. An enquiry into the origins of cultural change. Oxford, UK: Blackwell. 
Husserl, E. (1970). The crisis of European sciences and transcendental phenomenology: An introduction to phenomenological philosophy. Evanston, Il: Northwestern University Press. (Original work published 1937)

Jameson, F. (1991). Postmodernism or, the cultural logic of late capitalism. London, UK: Verso.

Jones, S. G. (1995). CyberSociety - Computer-mediated communication and community. Thousand Oaks, CA: Sage Publications.

Kumar, K. (2002). The nation-state, the European Union and the transnational identities. In N. N. AlSayyad and M. Castells (Eds.), Muslim Europe or Euro-Islam: politics, culture, and citizenship in the age of globalization (pp. 53-68). Oxford, UK: Lexington Books.

Kunstler, J. H. (1993). The geography of nowhere: The rise And decline of America's man-made landscape. New York, NY: Simon \& Schuster.

Lacan, J. (1993). The seminar. Book III. The psychoses, 1955-1956. London, UK: Routledge. (Original work published 1955-1956)

Laclau, E., \& Mouffe, C. (1987). Post-Marxism without apologies. New Left Review I/166, November-December, 79-106.

Laclau, E. (1990). New reflections on the revolution of our time. London, UK: Verso.

Laclau, E. (2005). Philosophical roots of discourse theory. Centre for Theoretical. Studies in the Humanities and Social Sciences, Essex University. Unpublished paper.

Laclau, E. 2006. On populist reason. London, UK: Verso.

Lipovetsky, G., \& Sebastien, C. (2005). Hypermodern times. Cambridge, UK: Polity.

Lyotard, J.-F. (1984). The postmodern condition: A report on knowledge. Manchester, UK: Manchester University Press. (Original work published 1979)

Mura, A. (2012). A genealogical inquiry into early Islamism: The discourse of Hasan alBanna. Journal of Political Ideologies, 17(1), 61-85.

Negri, A., \& Zolo, D. (2005). L'Impero e la moltitudine - Un dialogo sul nuovo ordine della globalizzazione (The empire and the multitude - A dialogue over the new order of globalisation). Jura Gentium - Rivista di filosofia del diritto internazionale $e$ della politica globale, I, 1. Retrieved 1 October 2011, from http://www.juragentium.unifi.it/it/surveys/wlgo/negri.htm

Newman, S. (2009). The politics of postanarchism. Edinburgh, UK: Edinburgh University Press.

Nunes, M. (1995). Baudrillard in cyberspace: Internet, virtuality, and postmodernity. Style, 29(2), (Summer), 314-327.

Olalquiaga, C. (1992). Megalopolis: Contemporary cultural sensibilities. Minneapolis, MN: University of Minnesota Press.

Recalcati, M. (2010). L'uomo senza inconscio. Milano, Italy: Raffaello Cortina Editore.

Relph, E. (1976). Place and placelessness. London, UK: Pion.

Rodríguez Magda, R. M. (2005). Transmodernidad. Barcelona, Spain: Anthropos.

Roy, O. (2004). Globalized Islam - Fundamentalism, deterritorialization and the search for a new Ummah. London, UK: Hurst.

Sadiki, L. (2004). The search for Arab democracy - Discourses and counter discourses. London, UK: C. Hurst \& Co.

Soja, E. W. (1989). Postmodern geographies: The reassertion of space in critical social theory. London, UK: Verso.

Stone, A. R. (1996). The war of desire and technology at the close of the mechanical age. Cambridge, MA: MIT Press.

Taylor, C. (1991). The malaise of modernity. Toronto, Canada: Anansi.

Language and Psychoanalysis, 2012 (1), 68-87.

http://dx.doi.org/10.7565/landp.2012.0005 
Tocqueville, A. de (2007). Democracy in America. Stilwell, KS: Digireads.com Publishing. (Original work published 1835-1840/1863)

Turkle, S. (1995). Life on the screen: Identity in the age of the Internet. New York, NY: Simon and Schuster.

Tort, M. (2007). La fin du dogme paternal. Paris, France: Flammarion.

Virilio, P. (1991). The aesthetics of disappearance. New York, NY: Semiotext(e).

Virno, P. (2004). A grammar of the multitude: For an analysis of contemporary forms of life. Los Angeles, CA: Semiotext (e).

Weber, M. (1946). Science as a vocation. In H. Gerth and C. Wright Mills (Eds.), From Max Weber: Essays in sociology (pp. 129-156). New York, NY: Oxford University Press. (Original work published 1918)

Zielonka, J. (2006). Europe as empire: The nature of the enlarged European Union. Oxford, UK: Oxford University Press.

Zizek, S. (2000). The ticklish subject - The absent centre of political ontology. London, UK: Verso. 